\title{
Shades of Silver: Applying the Strategic Diversity Manifesto to Tennessee's Knox County Office on Aging
}

\author{
Joseph Winberry, University of Tennessee, Knoxville, USA
}

\begin{abstract}
This article applies the Strategic Diversity Manifesto-originally designed for evaluating inclusion of diversity among the information resources of public libraries-to aging services. Aging services is the collection of organizations and resources that serve the fastest growing population in the world-older adults. This application is accomplished through the methods of website evaluation and participatory assessment. The result of this case study is a specific adaptation of the Strategic Diversity Manifesto to the Office on Aging in Knox County, Tennessee, U.S., indicating how aging services organizations can build on their existing services and outreach to diverse elder populations through their organizational information resources. For this study, diversity among older adults is represented specifically through the "members of ethnic and racial minority groups," "people with disabilities," "LGBTQ people," "immigrants/refugees," and "low-income people" categories.
\end{abstract}

Keywords: aging services; diversity; elder abuse; intersectionality; older adults

Publication Type: research article

\section{Introduction}

P opulations around the globe are aging (United Nations, 2015). This increased aging is accompanied by growing diversity (Kolko, 2016; Petriwskyj, Warburton, Everingham, \& Cuthill, 2012; Warnes, Friedrich, Kellaher, \& Torres, 2004; Wilson, 2017). Diversity within aging populations presents many challenges and opportunities for the future of aging-related information resources. How are aging services-organizations such as local offices on aging designed to serve their community's rising older population with resources like meals, socialization, and transportation-responding to diversity among older adults (Morrow-Howell \& Hasche, 2013)? This article explores the U.S. Knoxville-Knox County Community Action Committee Office on Aging (Office on Aging), ${ }^{1}$ located in the city of the Knoxville, Tennessee, as a case study for exploring this question.

This Office on Aging case study provides valuable lessons for the rest of the world due to shared characteristics. By 2050, people age 60 years and older will outnumber those 24 years and younger so most nations will inevitably grapple with how to serve a growing aging population (United Nations, 2015). As the world's population ages, it also continues a trend of migration from rural to urban settings-arguably making midsize communities like Knoxville a microcosm of the emerging state of global aging (Fitzgerald \& Caro, 2014). Aging services in other countries such as Spain have a similar emphasis on caregiving, senior housing, socialization, and long-term care (Fuster, 2017). Even in so-called "developing countries," the need for infrastructure 
necessary for supporting a growing aging population has been noted for decades (Shrestha, 2000). These shared characteristics make studying elder diversity among information resources of a midsize community in the U.S. helpful for those interested in these topics elsewhere-especially if Internet access continues to extend to rural and low-income areas around the globe (West, 2015).

The question of how aging services are responding to growing diversity among older adults is addressed by examining the Office on Aging's information resources through application of the Strategic Diversity Manifesto conceptual framework. This framework provides a means of evaluating content available on the office's website. Insight is also derived from the participatory assessment of the author, who was embedded as both a student and as an employee in the Office on Aging's Elder Abuse Community Outreach program at the time of this study. ${ }^{2}$

\section{Introducing the Strategic Diversity Manifesto}

The Strategic Diversity Manifesto was designed to offer public libraries a way to purposely address issues of diversity within their information resources through the method of website evaluation (Mehra \& Davis, 2015). Libraries are able to measure the inclusion of diverse populations within their information resources via the manifesto's "who," "what," and "how" components. These components provide a model for purposeful work towards increasing and showcasing organizational diversity.

The "who" component of the Strategic Diversity Manifesto was conceptualized with the understanding that there has been an increased focus on users within the information science field going back several decades (Faiks \& Hyland, 2000; Kuhlthau, 1991; Weigl \& Guastavino, 2011). Dervin \& Nilan's (1986) “Information Needs and Uses" has been cited more than 1,700 times according to Google Scholar; a review of the literature indicates that their article is seen as the starting point for a greater user focus within the field of information sciences (Olsson, 2016). Indeed, several user studies have been conducted with a focus on diverse populations around the world (Devi \& Dlamini, 2014; Lupien, 2007; Tennakoon, Saridakis, \& Mohammed, 2018). However, Mehra and Davis (2015) identify gaps in this focus: "what is missing, however, from current practice is a holistic identification, analysis and description of users in terms of their psychological, behavioral and demographic attributes as contextualized in response to localized environments" (p. 19). Their discussion of these missing aspects of identification produced nine categories for analyzing the "who," including age.

The "what" component recognized seven subcategories for reviewing information resources as they relate to diversity. The three overarching themes of these categories are: information sources, information policy and planning, and connections (both internal and external). While the seven subcategories within these three broad themes were originally developed to measure public library resources, they are helpful, with some modification, in measuring information resources in aging services organizations.

The "how" component of the Strategic Diversity Manifesto provides search strategies for identifying the "who" and "what" components on websites being evaluated. The strategies deployed by Mehra and Davis (2015) included search engine searches and searches of the public library websites as applicable.

While the Strategic Diversity Manifesto does establish nine categories for representing diversity in information resources, Mehra and Davis (2015) explain that "the categories are representative, not to be considered all-encompassing in any manner, and individual agencies should identify

The International Journal of Information, Diversity, \& Inclusion, 2(4), 2018

ISSN 2574-3430, publish.lib.umd.edu/IJIDI/ 
and create additional categories or modifications based on a community analysis of patrons in their local regions and areas" (p. 20). In order to help identify categories for evaluation, it is important to understand the community context of the organization being evaluated.

\section{The Community Context}

In order to understand the situational context of Tennessee's Knox County Office on Aging and the information offerings it provides to meet the needs of its audiences, it is important to describe the community in terms of its environmental characteristics, its cultural and social settings, its agency's profile, and its community and user stakeholders.

\section{Environment and Setting}

Knoxville is the third largest city by population in the state of Tennessee (City of Knoxville, n.d.). It is situated in Knox County, itself the third most populated county in the state after Shelby and Davidson (U.S. Census Bureau, 2018). Greater Knoxville's scenic geography, low cost of living, economic growth, and high quality of life is expected to empower the city's development over the coming decades (Knoxville-Knox County Metropolitan Planning Commission, 2003). In order to look more specifically at how Knoxville's geographic and cultural environment impacts diversity-diversity among older adults particularly-the author applied a select SWOT analysis of the community.

Among Knoxville's strengths as a space for increased recognition of diversity among older adults is its geographic and cultural environment, which is seen as a hospitable location for retirees (WBIR Staff, 2017). Over time, this hospitality could assist in the development of a more diverse population base of older adults. A second strength of Knoxville as it relates to older adult diversity is the community's wide-ranging non-profit organizations. Brundige (2017) lists several Knoxville-area non-profit organizations that focus their services on Latinos, people of color, people with intellectual or physical disabilities, refugees, and people in rural settings ("Knoxville Mercury's Giving Guide"). The state's flagship university-rooted in Knoxville-is marshaling its resources in support of prioritizing diversity and inclusion, thus increasing the footprint of diversity-minded non-profits in the area (The University of Tennessee Knoxville, n.d.). These organizations offer a charitable framework that can be helpful to older adults of various backgrounds and experiences.

Though the number of diverse focused non-profits is a strength for older adults, the author's experience has been that many of these non-profits are not focused on serving older adults. An exploration of diverse organizations and their ideas around elder abuse showed that aging services and diverse organizations can identify more common ground for working towards shared goals (Knoxville-Knox County Community Action Committee [CAC] Office on Aging, n.d.-b). A second weakness is Knoxville's apparent contradictions on diversity issues. This struggle is exemplified in local media, such as a blog post repudiating claims that Knoxville is one of the most LGBTQ friendly cities in America (Knoxville Urban Guy, 2012). Juxtaposing the blogger's critique with the mayor's page on LGBTQ equality, however, suggests that political power is currently supportive of the local LGBTQ community (Rogero, n.d.). This split in attitudes may be seen in views on immigrants and other diverse groups as well, prompting questions about the extent of Knoxville's commitment to ensuring the longtime stability of diverse members of its community (Whetstone, 2017).

A major opportunity to address these issues exists in the possibility of increased developmental

The International Journal of Information, Diversity, \& Inclusion, 2(4), 2018

ISSN 2574-3430, publish.lib.umd.edu/IJIDI/ 
collaboration between organizations serving diverse populations and the county aging services providers (Selsky \& Parker, 2005). The size of the Office on Aging-it has 24 programs and \$5.6 million in annual revenue-indicates that there is an opportunity to expand services in diverse communities (Knoxville-Knox County CAC Office on Aging, n.d.-f).

Federal funding made up nearly half of the Office on Aging revenue last year (Knoxville-Knox County CAC Office on Aging, n.d.-f). Budget rumblings and changing attitudes in national politics could threaten the major funding source for aging services programs, just as the world begins to age rapidly (United Nations, 2015). Building new or strengthening existing partnerships with organizations serving diverse populations will help defend against the routine funding challenges faced by public service organizations (Giesecke, 2012).

\section{Agency Profile}

The Office on Aging is a department of the Knoxville-Knox County Community Action Committee (CAC). Both entities are products of the Great Society and War on Poverty legislation of the 1960s (Frusciante, 2007). As such, both work to bolster the economic and social stability of vulnerable populations such as the elderly, people with low to moderate income, people with disabilities, and unemployed individuals, among others (Knoxville-Knox County Community Action Committee, n.d.). Community action organizations exist across Tennessee and across the U.S. They serve as the repository of many of the same federal programs such as utility assistance, home weatherization, and meals for homebound and/or elderly people. Despite these similarities, each community action organization offers varying programs of differing scale and composition based on the needs of the community they serve (Community Action Partnership, 2018). The CAC began as a partnership of the local city and county governments; since its formation in the 1960s, the CAC has worked through its departments to offer transportation, aging services, energy assistance, community development, urban agriculture, and other services to in-need citizens of Knox County (Knoxville-Knox County Community Action Committee, n.d.).

\section{Community and User Profile}

About 60,514 or $13 \%$ of Knox County citizens are estimated to be age 65 years or older (U.S. Census Bureau, 2014a). Figure 1 illustrates the racial and ethnic breakdown of this population. Figure 2 showcases the numbers of older Knoxvillians who are foreign born, have disabilities, and those who are considered low-income. While the U.S. Census Bureau does not collect information on LGBTQ individuals, one estimate by LGBTQ demographers at the University of California Los Angeles suggests that the county level representation of LGBTQ individuals is arguably comparable to the statewide estimate of $2.6 \%$ or 11,459 (Williams Institute, personal communication, May 12, 2016; Gates \& Newport, 2013). If this percentage were constant for county dwellers age 65 years and older, the approximate number of older LGBTQ Knoxvillians would be 1,573. In addition to existing diversity, future projections suggest further reasons for increasing service provision to diverse elders. Between 2016 and 2066, the share of the nonwhite percentage of Knox County's entire population will more than double from $17 \%$ to $35 \%$ with the increase of approximately 149,555 non-white individuals (Boyd Center for Business and Economic Research, 2017). Based on this estimate, it may be fair to suggest that diversity will increase in other areas-including the categories outlined in Figure 2. As such, outreach to diverse populations is as much about the future of aging services as it is the present. While demographics help illustrate "diversity among older adults," a literature review is necessary for understanding how this term has been represented in the existing scholarship. 


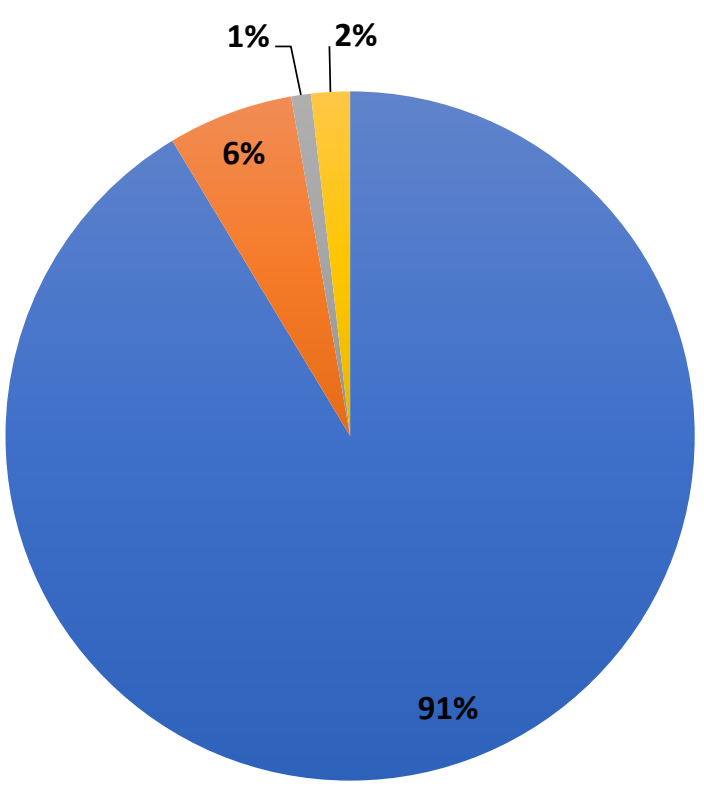

White

Black or African American

Hispanic

Other

Figure 1. Race/Ethnicity Among Knox County Older Adults: 2014

Source. U.S. Census Bureau, 2010-2014 American Community Survey 5-Year Estimates

\section{Literature Review}

The author reviewed select literature for assistance in defining "diversity among older adults" within an information context. The initial focus of the search was on two databases of the information sciences: Library, Information Science \& Technology Abstracts (LISTA) and Library \& Information Science Source. Findings showed that one interpretation of diversity among older adults stemmed from cultural differences between younger old and older old individuals (van Boekel, Peek, \& Luijkx, 2017). Gonçalves et al. (2017) wrote on the need to develop smartphone interfaces that account for the diversity of older adults, arguing that their diversity "can be attributed to decades of varied experiences" (p. 129). In a 2015 study of older adult student learning in an academic library, Aagard, Antunez, and Sand concluded that diversity within this non-traditional cohort was "often accompanied by additional characteristics beyond age such as technology proficiency, ethnicity, and differing educational cultures" (p. 218). A separate study of older adult social media use built on this idea, showing that other socio-cultural factors beyond age such as gender, race/ethnicity, and income level affected the extent to which older adults used social media (Yu, Ellison, McCammon, \& Langa, 2016). These findings indicate that diversity among older adults should be understood broadly and defined to include a variety of socio-cultural aspects as appropriate for each separate study. 


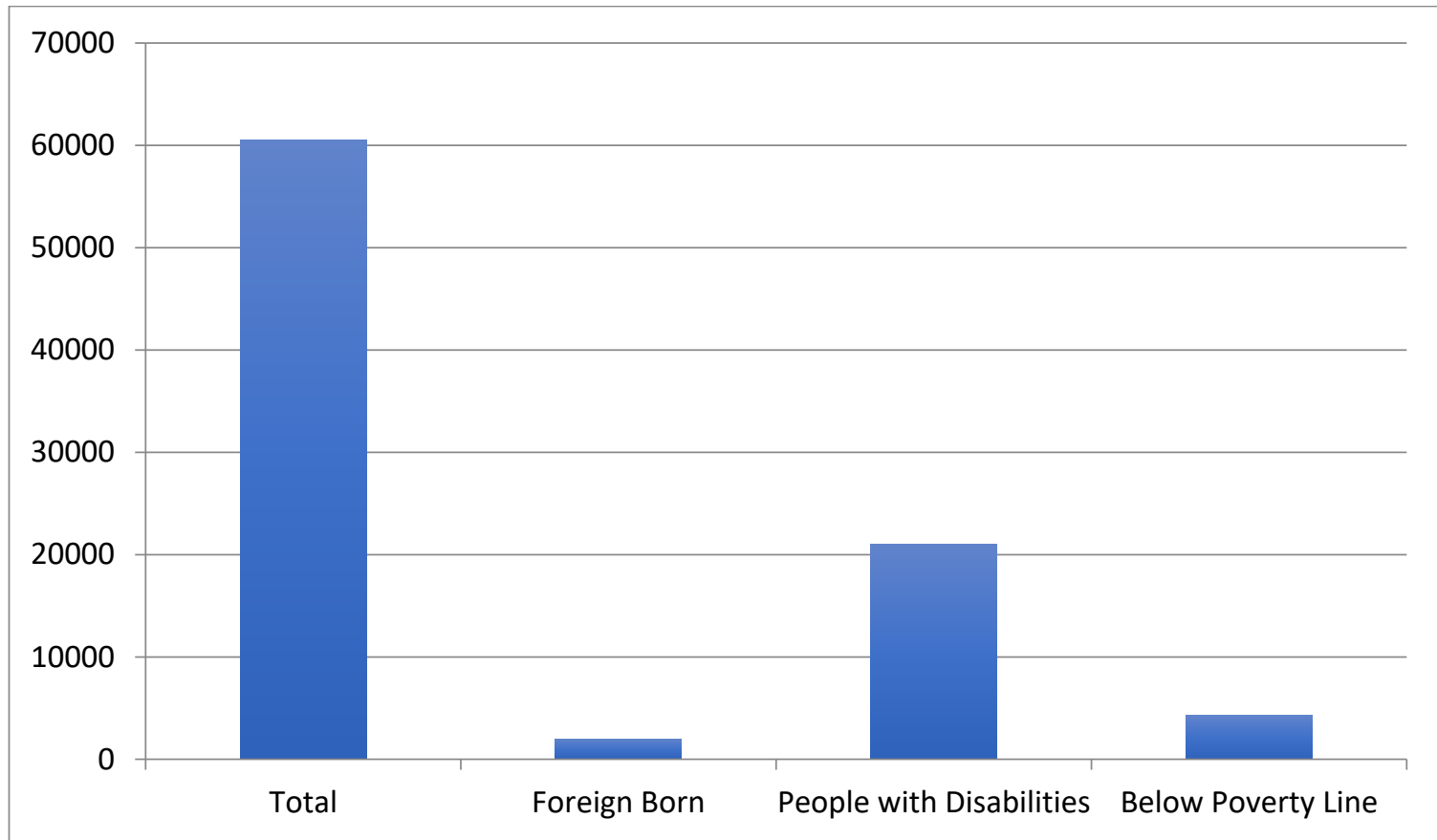

Figure 2. Foreign Born Status, Disabilities, and Low-Income Among Knox County Older Adults Source. U.S. Census Bureau, 2010-2014 American Community Survey 5-Year Estimates

For the purposes of this article, the author sought out additional research on diversity among older adults as it intersected with race/ethnicity, disability, sexuality, gender identity, immigration or refugee status, and income level. These additional works were found through other avenues that included Google Scholar, Internet searches, and bibliographic reviews. One study found that race and age impact the perceived approachability of librarians (Daniel, 2013). Another looked at the health information-seeking habits of older African American women (Gollop, 1997). An exploration of health consumer information for the LGBTQ community acknowledged that older LGBTQ people face additional health information needs related to longterm health, housing, and human services decisions (Flemming \& Sullivant, 2000). Bonnici, Maatta, Wells, Brodsky, and Meadows (2012) indicated the need for further emphasis on services to people with disabilities in library and information science education, as large swaths of society could find themselves in this category, including aging individuals. Khvorostianov, Elias, and Nimrod (2012) examined the role of the Internet in the lives of aging immigrants to Israel: "Memories of the past played an important role in the participants' current lives and were expressed in many of their Internet uses. These uses may be divided into two different perspectives of the past: the personal past and the national history" (p. 591). Similarly, another article noted the importance of the Internet in the personal health care management of lowincome individuals who were homebound or had disabilities (Choi \& DiNitto, 2013).

The select literature review uncovered several studies that explored intersections between older adults and diverse populations in an information context-both in the U.S. and around the world. Several of the reviewed works were related to health information. This article, in contrast, emphasizes the representation of diverse older adults within aging services organizations' information resources. The analysis below is conducted through the adaptation and application of the conceptual framework of the Strategic Diversity Manifesto. 


\section{Methodology}

This article has evolved from work conducted by the author in a graduate level course on diversity and inclusion within an information management setting. ${ }^{3}$ When asked to consider an appropriate organization for the course project, the author considered his personal interest in diversity among older adults as well as his professional experience working at the Knox County Office on Aging. Participatory assessment has been used in similar studies in which the benefits have outweighed the potential concerns (Lenstra, 2017; Mehra \& Braquet, 2007). The "embedded" author as a reflective practitioner, as prescribed by Schön (1987), was able to utilize his experience in aging services to adapt the Strategic Diversity Manifesto for aging services organizations and provide specific next steps for the Office on Aging based on the analysis of the results.

In order to evaluate the representation of diversity among the Office on Aging's information resources, the Strategic Diversity Manifesto was adapted and applied to the agency's website, http://www.knoxseniors.org. This helped explain to what degree the Office on Aging is responding to growing diversity among older adults. Websites allow for greater replicability of evaluations, but, when adopting content analysis and website evaluation as research methods, challenges in objectivity arise as well as challenges in the form of regular updates to website content.

\section{Applying the Strategic Diversity Manifesto}

"Who" terms helped to identify the population group for which the author searched in the Office on Aging's information resources. This article explores the representation of diversity amongst older adults in the context of the "who" component of the Strategic Diversity Manifesto. As such, the "who" terms identified in Table 1 represent some broad diverse categories which were chosen based both on the community context and on select gaps noticed by the author during his participatory assessment. While these categories are admittedly limited and generalized, they support this study's efforts to review multiple forms of diversity as they intersect with age (Cooke, 2017; Cronin, 2010; Koehn, Neysmith, Kobayashi, \& Khamisa, 2013). Furthermore, the broad nature of the selected categories allow them to be applied more easily to various communities throughout the world. Future studies may identify additional or different categories for analysis.

For instance, while gender is one of the categories outlined in the original Strategic Diversity Manifesto, the author decided against including consideration of cisgendered individuals within this adaptation as this category did not occur as frequently as others in the community context research or in the author's participatory assessment. Additional research also supported the decision. Men have been thought of as a minority group in the information sciences with studies showing that men use libraries and information services much less frequently than women (Applegate, 2008; Laroche, Saad, Cleveland, \& Browne, 2000). However, not all gender-related research is in agreement. An international context suggests that women face more access and use challenges in the digital age (Ono \& Zavodny, 2005; Terry \& Gomez, 2010). Researchers who see gender as an equally important category are not mistaken, but no one article can capture every category or aspect of diversity (Cooke, 2017).

Rather than make a judgment about which categories were most important, the author decided to focus on characteristics that were brought up the most in his participatory assessment. One expectation is that the findings of this article will promote future research which examines the

The International Journal of Information, Diversity, \& Inclusion, 2(4), 2018

ISSN 2574-3430, publish.lib.umd.edu/IJIDI/ 
intersection of older adults and more specific diverse groups within the broader "who" terms listed as well as within other diverse population categories.

Table 1. Defining “Who” Terms Searched for Within Office on Aging's Information Resources

\begin{tabular}{ll}
\hline Term & Definition \\
\hline Members of racial and ethnic minority groups & $\begin{array}{l}\text { Older adults who represent a wide range of } \\
\text { racial and/or ethnic groups. }\end{array}$ \\
People with disabilities & $\begin{array}{l}\text { Older adults experiencing physical, } \\
\text { intellectual, or cognitive challenges. }\end{array}$ \\
LGBTQ people & $\begin{array}{l}\text { Older adults who identify as Lesbian, Gay, } \\
\text { Bisexual, Transgender, or Queer. }\end{array}$ \\
Immigrants/Refugees & $\begin{array}{l}\text { Older adults who were not born in the U.S., } \\
\text { but came to the county at some point after } \\
\text { birth for any reason, including in order to } \\
\text { escape political, social, and economic } \\
\text { conditions in their home country. }\end{array}$
\end{tabular}

Older adults who lack financial resources.

Table 2 represents the "what" component of the Strategic Diversity Manifesto. Adapted from the original framework, these categories better represent the information resources of the aging services field. Together with the "who" terms, they frame the searches performed on the Office on Aging website for resources related to diversity as represented by the "how" of website evaluation.

Table 3 summarizes the quantified results of the website evaluation. A point was assigned for every "who" term that appeared in a "what" category. Since diversity of race or ethnicity, ability, and income level were represented in the office's senior service directory, one point (i.e., 1) each was assigned to the corresponding external resources cells. If a "who" term was not represented in a "what" category, then zero points (i.e., 0) were assigned to that particular unit. As such, zero points were assigned anywhere in the diversity commit tee category as there was no mention of a diversity board or diversity-focused board member for any of the "who" terms on the organization's website.

The "how" of website evaluation has revealed evidence of diversity and inclusion amongst the Office on Aging's information resources. Table 4 fleshes out many of the findings in Table 3 by addressing specific examples of adherence to diversity on the website. For instance, pictures are described as being inclusive of numerous racial and ethnic groups. Examples of regular incorporation of people with disabilities and those with low income can be seen in several categories, such as news and upcoming events. Together these findings indicate strengths and areas for enhancement. 
Table 2. The "What" Component of the Strategic Diversity Manifesto

\section{A. Information Sources}

A.1 External Resources (e.g., senior service directories, resource lists)

External resources are an important part of an organization's outreach and connection to their community. In the researcher's experience, senior service directories are an important part of the work that aging services provide to older adults. Seeing how diversity is represented in the resources the Office on Aging provides to the public will help to illuminate the organization's discussion of diversity in the community.

A.2 Internal Resources (e.g., annual report, social media, job listings)

As in public libraries, internal information resources of aging services organizations can take many forms. The focus for this project has been both print and digital resources such as the annual reports as well as social media.

B. Information Policy and Planning

B.1 Diversity committee or recognized diversity-focused member of board (e.g., identification of committee member's contact information)

While diverse representation among an organization's board or aging council is important, designating a committee or individual who represents the organization's approach to diversity matters is a step in the right direction.

B.2 Diversity representation (e.g., diversity statement, inclusion in needs assessment, pictures, etc.)

How does the Office on Aging represent diversity? Pictures are an important way that organizations visually describe their work or mission. Articulating a diversity statement on the website is an easy, subtle, yet powerful way of conveying the organization's values as they relate to matters of diversity and inclusion.

\section{Connections (Internal and External)}

C. 1 Centers and organizations, departments and offices (e.g., mention of diversity in different program webpages)

While an organization can represent diversity as an enterprise-wide value, there are some individual programs or services that can also represent specific outreach to diverse populations.

C.2 Community engagement (e.g., connections to external community-based diversity agencies)

How well does the organization showcase partner organizations that serve diverse older adults?

C.3 News and upcoming events (within the past one year) (e.g. information on internal/external activities and events)

Do news and events from the aging organization represent a commitment to diversity? 
Several of the information subcategories saw each of the "who" terms included. These were internal information resources, diversity representation, centers and organizations, and community engagement. Findings suggest that within their own internal resources, the Office on Aging is including a wide range of diverse populations. Additionally, people from various races and ethnicities, people with disabilities, and people with low incomes were represented in six of seven categories, suggesting very high inclusion of these groups. Overall, the results were encouraging, as no "who" term was represented less than four times. Additionally, only one "what" category-external resources-saw fewer than three mentions. Increasing connections to outside organizations serving diverse populations-such as LGBTQ and immigrant/refugee-serving organizations-will build on current levels of inclusion.

LGBTQ and immigrant/refugee information resources were the least present out of all the resources for diverse population groups. LGBTQ elders were not represented in external resources, meaning that those who were seeking LGBTQ-specific resources in the community would not be able to find them in the Office on Aging's senior service directory or online resource lists. There are reasons for why the Office on Aging should consider increasing inclusion of these populations moving forward. First, the advent of marriage equality in countries across several continents removed historic barriers to LGBTQ couples revolving around aging, incapacity, and end-of-life care (Almack, Seymour, \& Bellamy, 2010). Second, the attainment of marriage equality nationwide in 2015 has led to a $23 \%$ increase of same-sex marriages in the U.S. in just over two years (Masci, Brown, \& Kiley, 2017). Older LGBTQ couples-including those who are or are not legally married-should be able to see the Office on Aging as a resource now and in the future.

More immigrants and refugees are settling into the Knoxville area than ever before-part of global migration shifts that affect many countries (Scott, 2017). The author's conversations with local law enforcement suggest that there will be a need for more community support between law enforcement and the growing refugee population in particular as language and cultural barriers will require increased competencies and resources (anonymous Knoxville law enforcement officers, personal communication, n.d.). The Office on Aging's historic support for the area's aging population makes it a natural fit for assisting both law enforcement as well as older immigrants and refugees in the future (Knoxville-Knox County CAC Office on Aging, n.d.-b).

Lastly, the Office on Aging has realized the power of social media in advancing an inclusive and diverse message to the community. Although the author's own Elder Abuse Community Outreach program has contributed some to this effort, the Office on Aging staff with whom he has interacted understand that diversity is important and see social media outreach as one of the more effective ways of reaching out to underserved or overlooked populations (Knoxville-Knox County CAC Office on Aging staff, personal communication, n.d.).

Overall, the results bode well for scaling services to meet the need of future growth among diverse seniors. However, the organization must not be complacent in strategic planning. Between 2016 and 2066, the number of people in Knox County age 65 years and older is expected to nearly double from 69,105 to 130,575 (Boyd Center for Business and Economic Research, 2017). The population that the Office of Aging of the future will serve will be a starkly different one in the sense of sheer numbers; this shift will likely extend to the level of diversity as well. Efforts must be made now to ensure the successful embrace of diversity that future elders will require.

The International Journal of Information, Diversity, \& Inclusion, 2(4), 2018 ISSN 2574-3430, publish.lib.umd.edu/IJIDI/ 
Table 3. The Quantified Results of the Website Evaluation Represented in a Checklist

\begin{tabular}{|c|c|c|c|c|c|c|c|c|}
\hline $\begin{array}{l}\text { What Terms } \\
\rightarrow\end{array}$ & \multicolumn{2}{|c|}{$\begin{array}{l}\text { A. Information } \\
\text { Sources }\end{array}$} & \multicolumn{2}{|c|}{$\begin{array}{l}\text { B. Information } \\
\text { Policy }\end{array}$} & \multicolumn{3}{|c|}{$\begin{array}{l}\text { C. Connections } \\
\text { (Internal and } \\
\text { External) }\end{array}$} & \multirow{2}{*}{ TOTAL } \\
\hline$\downarrow$ & $\mathrm{A} 1$ & $\mathrm{~A} 2$ & B1 & B2 & $\mathrm{C} 1$ & $\mathrm{C} 2$ & $\mathrm{C} 3$ & \\
\hline $\begin{array}{l}\text { Members of racial and } \\
\text { ethnic minority groups }\end{array}$ & 1 & 1 & 0 & 1 & 1 & 1 & 1 & $6 / 7$ \\
\hline People with disabilities & 1 & 1 & 0 & 1 & 1 & 1 & 1 & $6 / 7$ \\
\hline LGBTQ people & 0 & 1 & 0 & 1 & 1 & 1 & 0 & $4 / 7$ \\
\hline Immigrants/Refugees & 0 & 1 & 0 & 1 & 1 & 1 & 0 & $4 / 7$ \\
\hline Low-income people & 1 & 1 & 0 & 1 & 1 & 1 & 1 & $6 / 7$ \\
\hline TOTAL & $3 / 5$ & $5 / 5$ & $0 / 5$ & $5 / 5$ & $5 / 5$ & $5 / 5$ & $3 / 5$ & \\
\hline
\end{tabular}

Table 4. The Qualified Results of the Website Evaluation Represented in a Chart

\begin{tabular}{|c|c|c|}
\hline What Terms & Who Terms Description & Evidence \\
\hline $\begin{array}{l}\text { A. } 1 \text { External } \\
\text { Resources }\end{array}$ & $\begin{array}{l}\text { When looking at the agency's senior } \\
\text { directory, there is the inclusion of multiple } \\
\text { racial/ethnic groups as well as clear } \\
\text { inclusion of people with disabilities and } \\
\text { those with low income. }\end{array}$ & $\begin{array}{l}\text { Knoxville-Knox County CAC } \\
\text { Office on Aging, n.d.-e }\end{array}$ \\
\hline $\begin{array}{l}\text { A. } 2 \text { Internal } \\
\text { Resources }\end{array}$ & $\begin{array}{l}\text { The Office on Aging's Twitter account } \\
\text { showcases their support for diversity and } \\
\text { inclusion. The annual report does in places } \\
\text { as well. }\end{array}$ & $\begin{array}{l}\text { Knoxville-Knox County CAC } \\
\text { Office on Aging, } 2018 \\
\text { Knoxville-Knox County CAC } \\
\text { Office on Aging, n.d.-f }\end{array}$ \\
\hline $\begin{array}{l}\text { B. } 1 \text { Diversity } \\
\text { Committee }\end{array}$ & $\begin{array}{l}\text { There is not a diversity committee or } \\
\text { member of the Council on Aging-the } \\
\text { organization's board-who is identified on } \\
\text { the website as being a diversity } \\
\text { representative. }\end{array}$ & $\begin{array}{l}\text { Knoxville-Knox County CAC } \\
\text { Office on Aging, n.d.-a }\end{array}$ \\
\hline
\end{tabular}




\begin{tabular}{lll}
$\begin{array}{l}\text { B.2 Diversity } \\
\text { Representation }\end{array}$ & $\begin{array}{l}\text { The website has pictures of people of } \\
\text { numerous races/ethnicities. The needs } \\
\text { assessment addresses many specific } \\
\text { populations including LGBTQ people. }\end{array}$ & $\begin{array}{l}\text { Knoxville-Knox County CAC } \\
\text { Office on Aging, n.d.-d } \\
\text { Knoxville-Knox County CAC } \\
\text { Office on Aging, 2017 }\end{array}$ \\
\hline $\begin{array}{ll}\text { C.1 } \\
\text { Departments }\end{array}$ & $\begin{array}{l}\text { The Elder Abuse Community Outreach } \\
\text { webpage contains the most explicit evidence } \\
\text { of diversity among older adults, although this } \\
\text { is seen in other parts of the website as well. }\end{array}$ & $\begin{array}{l}\text { Knoxville-Knox County CAC } \\
\text { Office on Aging, n.d.-b }\end{array}$ \\
$\begin{array}{ll}\text { C.2 Community } \\
\text { Engagement }\end{array}$ & $\begin{array}{l}\text { Within the last year, the Elder Abuse } \\
\text { Community Outreach Program has invited } \\
\text { members of diverse communities to present } \\
\text { to and serve on its committee. Descriptions } \\
\text { of these meetings are found in the minutes } \\
\text { on the program webpage. }\end{array}$ & $\begin{array}{l}\text { Knoxville-Knox County CAC } \\
\text { Office on Aging, n.d.-b }\end{array}$ \\
& $\begin{array}{l}\text { The news section of the website includes } \\
\text { links to the regular newsletter, Elder News } \\
\text { and Views. Together they represent inclusion } \\
\text { of diverse populations. }\end{array}$ & $\begin{array}{l}\text { Knoxville-Knox County CAC } \\
\text { Office on Aging, n.d.-c }\end{array}$ \\
$\begin{array}{ll}\text { News/Upcoming } \\
\text { Events }\end{array}$ &
\end{tabular}

\section{Strategic Plan}

While the Strategic Diversity Manifesto can provide a measurement of an organization's level of inclusion of diverse populations in information resources, the author's role as a participant researcher involved in assessment helped identify realistic, actionable goals for the organization based on insider knowledge of how the organization operates (Lofland \& Lofland, 1984; Dwyer \& Buckle, 2009). The following are select actions that the Office of Aging should pursue as next steps moving forward:

1. Add a diversity statement to the website. A blanket diversity statement that states something to the effect of "The Office on Aging respects and celebrates the diversity of all older adults in our community" is a small, easy, and seemingly inconsequential change that can speak volumes to the people who visit the website, as has been shown in other settings (Ihme, Sonnenberg, Barbarino, Fisseler, \& Stürmer, 2016; Yeo, Erikso Cornish, \& Meyer, 2017).

2. Add or appoint a diversity subcommittee or diversity representative (i.e., someone who encourages the Office on Aging to consider diversity inclusion opportunities) to the Council on Aging. The Council on Aging-the Office's advisory board-is charged with distributing Older Americans Act monies to many local organizations; it also advocates on behalf of county seniors to funders, political leaders, and other community stakeholders (Knoxville-Knox CAC Office on Aging, n.d.-a). Introducing a diversity subcommittee or even a member who helps keep the group conscious of the profile of diverse older adults could have a domino effect which gets all staff, volunteers, and community partners to consider the diversity of older adults in Knox County.

3. Include a diversity statement and additional diverse resources in the next iteration of 
the senior directory. The diversity statement could be the same message suggested for the website, but it may reach a different audience including older adults themselves who may pick up a copy of the directory at a community fair or senior center around the county. While diversity encompasses many meanings and need not be defined in any particular way, having resources related to different older adult groups (such as those discussed in this article: members of minority racial and ethnic groups, people with disabilities, LGBTQ people, immigrants/refugees, and low-income people) may allow the Office to better engage with diverse elders who may not feel comfortable with seeking help without having seen the diversity statement and specific resources related to their experience as an individual (Wicks, 2008; Cooke, 2017).

4. Identify Office on Aging champions within other non-profits representing specific diverse groups. By building on cultivated relationships with representatives of diverse communities, the Office on Aging can tap into new markets of financial support, community outreach, and clients. If there are local leaders in the Latinx or LGBTQ communities, for instance, who have been educated by the Office on Aging on the importance of aging issues within their specific communities, there may be an increased collaboration, which can have positive results beyond what is currently ascertained (Bond \& Keys, 1993).

These four steps represent different levels of involvement and integration; they provide differing solutions and levels of community engagement. Some of these steps are easier to implement than others. Nevertheless, the author believes all of them represent changes that can have a large and lasting effect on how the Knox County Office on Aging is understood as an organization actively seeking to assist diverse elders.

By making every effort to reach out to diverse populations within the community they serve, the Office on Aging can serve as a model for other aging services and non-library information management organizations hoping to provide information resources that are inclusive of diverse populations. The aging services adaptation of the Strategic Diversity Manifesto offers a framework that can be applied to existing or emerging aging services around the world, though more research is needed to see just how well the adaptation translates to the different types of diverse characteristics, community development, and aging services infrastructure that may be present in other countries.

\section{Conclusion}

The adaptation and application of the Strategic Diversity Manifesto in website evaluation and the author's participatory assessment indicated that the Office on Aging was inclusive of diverse elders within the organization's information resources, thus suggesting that the office was responding proactively to growing diversity among older adults. The strategic plan provided next steps for how the Office on Aging can build upon these findings and prepare for the expected increase of diversity among the growing elder population in Knox County, U.S. While the case study shares characteristics with many communities around the globe, more research is necessary to see just how well this adaptation can measure inclusion of diverse populations within the information resources of other aging services and non-library information management organizations around the world. 


\section{Acknowledgement}

The author would like to thank Dr. Bharat Mehra for his support and guidance during the completion of this article. The author would also like to thank his colleagues in our course for their ideas, examples, and camaraderie. Appreciation is extended as well to Dr. Keren Dali, the journal's editor, and to the anonymous reviewers who helped ensure that the article met the rigorous standards of IJIDI. Lastly, the author would like to thank the staff at the Office on Aging for the work they do to serve the older adults of Knox County, Tennessee, U.S.

\section{Endnotes}

1 The Knoxville-Knox County Community Action Committee's Office on Aging is referred to throughout the article as the Office on Aging for the sake of clarity. Similarly, the office's referenced information resources are cited as Knox County CAC Office on Aging to distinguish the Office on Aging from its parent organization, the Knoxville-Knox County Community Action Committee (CAC).

${ }^{2}$ In the time since this study was concluded, the program has begun transitioning into a new initiative titled: Rise Above Crime. This new initiative will provide case management and support group services to older victims as well as outreach and education to older adults, elder care professionals, and community members.

${ }^{3} \mathrm{~A}$ website was developed to encapsulate the author's participatory assessment experience at the Office on Aging. Interested readers can visit the website via the following link: http://inscdiversity.cci.utk.edu/jwinber1/

\section{References}

Aagard, M. C., Antunez, M. Y., \& Sand, J. N. (2015). Learning from degree-seeking older adult students in a university library. Reference Services Review, 43(2), 215-230.

Almack, K., Seymour, J., \& Bellamy, G. (2010). Exploring the impact of sexual orientation on experiences and concerns about end of life care and on bereavement for lesbian, gay and bisexual older people. Sociology, 44(5), 908-924.

Applegate, R. (2008). Gender differences in the use of a public library. Public Library Quarterly, 27(1), 19-31.

Bond, M. A., \& Keys, C. B. (1993). Empowerment, diversity, and collaboration: Promoting synergy on community boards. American Journal of Community Psychology, 21(1), 3757.

Bonnici, L. J., Maatta, S. L., Wells, M. K., Brodsky, J., \& Meadows, C. W. (2012). Physiological access as a social justice type in LIS curricula. Journal of Education for Library and Information Science, 53(2), 115-129. 
Boyd Center for Business and Economic Research. (2017). Boyd Center Tennessee population projections: 2016-2070. Retrieved from http://tndata.utk.edu/sdcpopulationprojections.htm

Brundige, H. (2016, November 22). Knoxville Mercury's giving guide to area nonprofits. Knoxville Mercury. Retrieved from https: / /www.knoxmercury.com/2016/11/22/knoxvillemercurys-giving-guide-area-nonprofits/

Choi, N. G., \& DiNitto, D. M. (2013). The digital divide among low-income homebound older adults: Internet use patterns, ehealth literacy, and attitudes toward computer/Internet use. Journal of Medical Internet Research, 15(5), e93.

City of Knoxville. (n.d.). Demographics. Retrieved from http://www.knoxvilletn.gov/visitors/knoxville_info/demographics/

Community Action Partnership. (2018). Partnership webinars. Retrieved from https://www.communityactionpartnership.com

Cooke, N. A. (2017). Information services to diverse populations: Developing culturally competent library professionals. Santa Barbara, CA: Libraries Unlimited.

Cronin, A., \& King, A. (2010). Power, inequality and identification: Exploring diversity and intersectionality amongst older LGB adults. Sociology: The Journal of the British Sociological Association, 44(5), 876-892.

Daniel, D. (2013). Gender, race, and age of librarians and users have an impact on the perceived approachability of librarians. Evidence Based Library \& Information Practice, 8(3), 73-75.

Dervin, B., \& Nilan, M. (1986). Information needs and uses. Annual Review of Information Science and Technology, 21, 3-33.

Devi, T. S., \& Dlamini, N. N. (2014). User studies of science graduates in University of Swaziland: A case study. International Journal of Information Dissemination \& Technology, 4(4), 308-311.

Dwyer, S. C., \& Buckle, J. L. (2009). The space between: On being an insider-outsider in qualitative research. International Journal of Qualitative Methods, 8(1), 54-63.

Faiks, A., \& Hyland, N. (2000). Gaining user insight: A case study illustrating the card sort technique. College \& Research Libraries, 61(4), 349-357.

Fitzgerald, K. G., \& Caro, F. G. (2014). An overview of age-friendly cities and communities around the world. Journal of Aging \& Social Policy, 26(1/2), 1-18.

Flemming, T., \& Sullivant, J. (2000). Consumer health materials for lesbians, gay men, bisexual and transgendered people. Public Library Quarterly, 18(3/4), 95-107.

Frusciante, A. (2007). Community action program. In G. L. Anderson \& K. G. Herr (Eds.), Encyclopedia of activism and social justice (Vol. 1, pp. 375-378). Thousand Oaks, CA: SAGE Publications Ltd. 
Fuster, V. (2017). Changing demographics: A new approach to global health care due to the aging population. Journal of the American College of Cardiology, 69(24), 3002-3005.

Gates, G. J., and Newport, F. (2013, February 15). LGBTQ percentage highest in D.C., lowest in North Dakota. Retrieved from http://news.gallup.com/poll/160517/LGBTQpercentage-highest-lowest-north-dakota.aspx

Giesecke, J. (2012). The value of partnerships: Building new partnerships for success. Journal of Library Administration, 52(1), 36-52.

Gollop, C. J. (1997). Health information-seeking behavior and older African American women. Bulletin of the Medical Library Association, 85(2), 141-146.

Gonçalves, V. P., de Almeida Neris, V. P., Seraphini, S., Dias, T. C. M., Pessin, G., Johnson, T., \& Ueyama, J. (2017). Providing adaptive smartphone interfaces targeted at elderly people: An approach that takes into account diversity among the elderly. Universal Access in the Information Society, 16(1), 129-149.

Ihme, T. A., Sonnenberg, K., Barbarino, M., Fisseler, B., \& Stürmer, S. (2016). How university websites' emphasis on age diversity influences prospective students' perception of person-organization fit and student recruitment. Research in Higher Education, 57(8), 1010-1030.

Khvorostianov, N., Elias, N., \& Nimrod, G. (2011). "Without it I am nothing": The internet in the lives of older immigrants. New Media \& Society, 14(4), 583-599.

Knoxville Urban Guy. (2012, March 06). Is Knoxville really one of the gayest cities in America? Inside of Knoxville. Retrieved from http://insideofknoxville.com/2012/03/isknoxville-really-one-of-the-gayest-cities-in-america/

Knoxville-Knox County Community Action Committee (CAC) Office on Aging. (n.d.-a). Council on aging. Retrieved from http://www.knoxseniors.org/coa

Knoxville-Knox County Community Action Committee (CAC) Office on Aging. (n.d.-b). Elder abuse community outreach program. Retrieved from http://www.knoxseniors.org/eacop/

Knoxville-Knox County Community Action Committee (CAC) Office on Aging. (n.d.-c). News \& events. Retrieved from http://www.knoxseniors.org/news

Knoxville-Knox County Community Action Committee (CAC) Office on Aging. (n.d.-d). Office on aging. Retrieved from http://www.knoxseniors.org

Knoxville-Knox County Community Action Committee (CAC) Office on Aging. (n.d.-e). Senior service directory. Retrieved from http://www.knoxseniors.org/ssd

Knoxville-Knox County Community Action Committee (CAC) Office on Aging. (n.d.-f). 20162017 annual report. Retrieved from http: //www.knoxseniors.org/report 
Knoxville-Knox County Community Action Committee (CAC) Office on Aging. (2017, July 1). 2017 Senior needs assessment report: Summary of May 11, 2017 program. Retrieved from http://www.knoxseniors.org/wp-content/uploads/Need-Assessment-ResultDocument.pdf

Knoxville-Knox County Community Action Committee (CAC) Office on Aging. (2018, March 30). CAC Office on Aging (@KnoxOOA) [Tweet]. Retrieved from https://twitter.com/KnoxOOA/status/979750550429368320

Knoxville-Knox County Community Action Committee. (n.d.). Knoxville-Knox county community action committee. Retrieved from http://www.knoxcac.org/newweb/

Knoxville-Knox County Metropolitan Planning Commission. (2003). Knoxville-Knox county general plan 2033. Retrieved from http://archive.knoxmpc.org/generalplan/Knox_GP2030.pdf

Koehn, S., Neysmith, S., Kobayashi, K., \& Khamisa, H. (2013). Revealing the shape of knowledge using an intersectionality lens: Results of a scoping review on the health and health care of ethnocultural minority older adults. Ageing \& Society, 33(3), 437-464.

Kolko, J. (2016, April 28). "Normal America" is not a small town of white people. FiveThirtyEight. Retrieved from https: / / fivethirtyeight.com/features/normal-americais-not-a-small-town-of-white-people/

Kuhlthau, C. C. (1991). Inside the search process: Information seeking from the user's perspective. Journal of the American Society for Information Science, 42(5), 361-371.

Laroche, M., Saad, G., Cleveland, M., \& Browne, E. (2000). Gender differences in information search strategies for a Christmas gift. Journal of Consumer Marketing, 17(6), 500-522.

Lenstra, N. (2017). The community-based information infrastructure of older adult digital learning: A study of public libraries and senior centers in a medium-sized city in the USA. Nordicom Review, 38(s1), 65-77.

Lofland, J., \& Lofland, L. H. (1984). Analyzing social settings: A guide to qualitative observation and analysis ( $2^{\text {nd }}$ ed.). Belmont, CA: Wadsworth.

Lupien, P. (2007). GLBT/sexual diversity studies students and academic libraries: A study of user perceptions and satisfaction. Canadian Journal of Information \& Library Sciences, $31(2), 131-147$.

Masci, D., Brown, A., \& Kiley, J. (2017, June 26). 5 facts about same-sex marriage. Retrieved from http://www.pewresearch.org/fact-tank/2017/06/26/same-sex-marriage/

Mehra, B. \& Braquet, D. (2007). Library and information science professionals as community action researchers in an academic setting: Top ten directions to further institutional change for people of diverse sexual orientations and gender identities. Library Trends, 56(2), 542-565.

Mehra, B. \& Davis, R. (2015). A strategic diversity manifesto for public libraries in the 21st century. New Library World, 116(1/2),15-36. 
Morrow-Howell, N., \& Hasche, L. (2008). Aging: Services. In Encyclopedia of Social Work. Retrieved from http://socialwork.oxfordre.com/view/10.1093/acrefore/9780199975839.001.0001/acr efore-9780199975839-e-513

Olsson, M. R. (2016). Re-thinking our concept of users. Australian Academic \& Research Libraries, 47(4), 286-299.

Ono, H., \& Zavodny, M. (2005). Gender differences in information technology usage: A U.S.-Japan comparison. Sociological Perspectives, 48(1), 105-133.

Petriwskyj, A., Warburton, J., Everingham, J., \& Cuthill, M. (2012). Diversity and inclusion in local governance: An Australian study of seniors' participation. Journal of Aging Studies, 26(2), 182-191.

Rogero, M. (n.d.). LGBTQ equality in Knoxville. Retrieved from http://www.knoxvilletn.gov/government/mayors_office/LGBTQ_equality_in_knoxville

Schön, D. A. (1987). Educating the reflective practitioner. San Francisco, CA: Jossey-Bass.

Scott, M. (2017, January 2). More refugees than ever before calling Knoxville home. Retrieved from https://www.wbir.com/article/news/local/more-refugees-than-ever-before-callingknoxville-home/51-381244023

Selsky, J., \& Parker, B. (2005). Cross-sector partnerships to address social issues: Challenges to theory and practice. Journal of Management, 31(6), 849-873.

Shrestha, L. B. (2000). Population aging in developing countries. Health Affairs, 19(3), 204-212.

Tennakoon, H., Saridakis, G., \& Mohammed, A. (2018). Child online safety and parental intervention: A study of Sri Lankan Internet users. Information Technology \& People, 31(3), 770-790.

Terry, A., \& Gomez, R. (2010). Gender and public access computing: An international perspective. The Electronic Journal of Information Systems in Developing Countries, 43(1), 1-17.

United Nations. Department of Economic and Social Affairs, Population Division. (2015). World Population Ageing 2015 (ST/ESA/SER.A/390). Retrieved from http://www.un.org/en/development/desa/population/publications/pdf/ageing/WPA2015 $\underline{\text { Report.pdf }}$

The University of Tennessee Knoxville (n.d.). Vol vision: Journey to the top. Retrieved from http://top25.utk.edu

U.S. Census Bureau. (2014a). 2010 census shows 65 and older population growing faster than total U.S. population. Retrieved from https://www.census.gov/newsroom/releases/archives/2010_census/cb11-cn192.html

U.S. Census Bureau. (2014b). 2010-2014 American Community Survey 5-Year estimate. Retrieved from https://factfinder.census.gov/faces/tableservices/jsf/pages/productview.xhtml?src=bkmk 
U.S. Census Bureau. (2018). Annual Estimates of the Resident Population: April 1, 2010 to July 1, 2017. Retrieved from https: / / factfinder.census.gov/faces/tableservices/jsf/pages/productview.xhtml?pid=P EP_2017_PEPANNRES\&prodType=table

van Boekel, L. C., Peek, S. T. M., \& Luijkx, K. G. (2017). Diversity in older adults' use of the internet: Identifying subgroups through latent class analysis. Journal of Medical Internet Research, 19(5), e180.

Warnes, A. M., Friedrich, K., Kellaher, L., \& Torres, S. (2004). The diversity and welfare of older migrants in Europe. Ageing \& Society, 24(3), 307-326.

WBIR Staff. (2017, March 13). Study finds Knoxville is the No. 1 place to retire early. Retrieved from http: / / www.wbir.com/article/money/magnify-money/study-finds-knoxville-isthe-no-1-place-to-retire-early/51-422022722

Weigl, D. M., \& Guastavino, C. (2011, October). User studies in the music information retrieval literature. Proceedings of the 12th International Conference of the Society for Music Information Retrieval (pp. 335-340). Miami, FL: ISMIR.

West, D. (2015). Digital divide: Improving Internet access in the developing world through affordable services and diverse content. Retrieved from https://www.brookings.edu/wp-content/uploads/2016/06/West_Internet-Access.pdf

Whetstone, T. (2017, June 29). Knox County approved for controversial ICE program. Retrieved from https://www.knoxnews.com/story/news/local/2017/06/29/knox-countyapproved-controversial-ice-program/439207001/

Whitfield, K., \& Baker, T. (2013). Handbook of minority aging. New York: Springer.

Wicks, D. A. (2008). Older adults and their information seeking. Behavioral \& Social Sciences Librarian, 22(2), 1-26.

Wilson, R. (2017, June 22). New census data: US growing older and more diverse. The Hill. Retrieved from http://thehill.com/homenews/state-watch/338776-new-census-dataus-growing-older-more-diverse

Yeo, V., Erickson Cornish, J. A., \& Meyer, L. (2017). An analysis of diversity content in doctoral health service psychology program websites. Training \& Education in Professional Psychology, 11(2), 86-93.

Yu, R. P., Ellison, N. B., McCammon, R. J., \& Langa, K. M. (2016). Mapping the two levels of digital divide: Internet access and social network site adoption among older adults in the USA. Information, Communication \& Society, 19(10), 1445-1464.

Joseph Winberry (jwinber1@vols.utk.edu) is currently a Master's of Information Sciences student at the University of Tennessee, Knoxville. He previously earned a bachelor's of history and political science from the University of North Carolina-Greensboro, graduating with honors. His interest in raising the profile of older adults in academic research stems from an affinity for 
elders that dates back to his childhood as well as from his experience working in elder abuse response work at his local Office on Aging. Future related research plans include investigating how older adults are represented in the information sciences literature; considering the role that information plays for older victims of crime; and identifying to what degree there is an interest in information and technology research among elder abuse response workers. 